\title{
SHAPING THE IMAGE AS A MANAGEMENT INSTRUMENT IN THE CONTEMPORARY ENTERPRISE
}

\author{
Wioletta WEREDA $^{1 *}$, Tomasz ZACŁONA ${ }^{2}$ \\ ${ }^{1}$ Institute of Organization and Management, Military University of Technology, Warsaw; \\ weredawioletta@tlen.pl, ORCID: 0000-0002-6948-0239 \\ ${ }^{2}$ Institute of Economics, State University of Applied Sciences in Nowy Sacz; za.to@interia.pl, \\ ORCID: 0000-0001-7729-1289 \\ * Correspondence author
}

Purpose: The main aim of the article is to identify the image-building process in the organization as a management instrument, from a theoretical standpoint, as well as from the practical one, based on initial research among top-level and middle-level managers from Polish collective accommodation facilities.

Design/methodology/approach: The present article is both theoretical and empirical. To achieve the goal adopted in the article, a survey aimed at managers of selected tourist accommodation establishments was conducted.

Findings: The research confirmed the established thesis that respondents' awareness of the treatment of image formation as a management instrument is quite high. In addition, empirical material indicates that the researched managers state that the strategic objective of managing the organization should be to build a positive image in the eyes of its stakeholders. The majority also say that the organization's image is its strategic resource and a factor of competitive advantage of the enterprise on the market, but on the other hand, the financing of imagebuilding activities is, according to respondents, a waste of money.

Research limitations/implications: The performed studies, due to their limited scope, cannot be used for generalizations and are treated by the authors themselves as pilot studies. The research covered three regions: southern, eastern, southwest. This choice was due to the personal availability of tourist managers of accommodation facilities located in these parts of Poland. As a result of the research, 112 correctly completed questionnaires were collected, which were used for analysis and inference. In the future, a similar research is planned to be done across Poland.

Practical implications: Based on the literature analysis and completed studies, the authors formulated recommendations for the managers of tourist accommodation facilities.

Social implications: The research might exert influence on organizational behavior of tourist accommodation establishments in building their image through effective internal and external communication.

Originality/value: The originality of the article is expressed through a subjective and objective scope of the study of image creation practice as a management instrument in tourist accommodation establishments. 
Keywords: shaping the image, management instrument, contemporary organization, collective accommodation facilities.

Category of the paper: Research paper.

"Everyone has their own image.

Once you find it, you better not lose it"

Audrey Hepburn

\section{Introduction}

The authors of the article recognize the growing importance of image as an intangible resource of an organization (intangible asset) and a factor that allows a company to achieve competitive advantage (Zacłona, 2010, p. 260), as well as its increasing role in organization management processes. They also attempted to determine the place and importance of shaping the image in the management structure of the surveyed entities. An indirect motivation to address this topic was to demonstrate in theory the correct handling of image shaping as a management instrument. The need to diagnose image formation as a management instrument results from terminological inaccuracies and the intuitive and imprecise use of the concept of the instrument in some scientific publications in the field of management. However, this is not surprising for the authors, because as $Ł$. Sułkowski notes, the basic concepts in the area of management are also controversial (Sułkowski, 2005, p. 15). Recognizing the lack of consensus as to the definition of the concept, the authors made, based on selected scientific literature, an attempt to define the concept of a management instrument, as well as to verify whether image shaping falls within its scope. In order for this task to be possible on the basis of literature studies, a definition of the image of the organization was adopted, which, in this study, is considered holistic, variable, but at the same time, a fairly lasting picture (Biedermann, Urbaniak, 1998, p. 17). This is that it is a set of beliefs, thoughts, impressions, perceptions and ideas that an individual or a specific stakeholder group has about a given organization. The above definition of the image does not refer to the possibility of its creation by the organization, which is why the authors explain that the organization understands image shaping as using instruments, methods, processes, strategies, concepts, procedures and tools, as well as management functions in order to create and maintain an appropriate image this organization (Tarczydło, 2013, p. 115). The purpose of the article is to present the image shaping process and demonstrate its role as a management instrument, both by querying the available literature, as well as by basing the assessment on collected empirical material obtained from a group of surveyed enterprises. The research methods used in the work are literature analysis and criticism, as well as a diagnostic survey given out among managers of the chosen enterprises. The article adopts the thesis that shaping the image is an important management tool and a factor influencing the building of relations with stakeholders. 


\section{Management instrument - an attempt to define and interpret}

In theoretical dissertations on management, the term 'instrument' is rarely defined - much more often it is used intuitively identified with method, technique or tool (Kowalczewski, Nazarko, 2006, p. 15). Indeed, the dictionary definition of the notion 'instrument' indicates that it is a way, method, principle of some action, a means for realizing something (Szymczak, 1982, p. 795). In the literature on management sciences, some authors also identify 'instrument' as a 'tool' (Kowalczewski, Nazarko, 2006, p. 17), which is treated as a whole of structured procedures and means used in organizational activities (Kowalczewski, Nazarko, 2006, p. 18). This approach is presented by K. Wojcik, who considered methods as superior concepts containing instruments, i.e. tools, which in turn are treated as broader concepts than techniques (Wojcik, 2005, p. 86). The scientific discourse also has the view that the management instrument is a concept with a much broader meaning than the management tool and is also a means of integrating management methods. Resolving this issue requires a broader perspective on the issue of management instrument.

It should be noted, after A. Stabryła, that the management function is implemented through the use of various management instruments (Stabryła, 2001, p. 32). Moreover, the proper use of a management instrument appropriate to the circumstances is the basis for creating the competitive advantage of the organization (Wąchol, 2010, p. 155). This suggests a diversity of management instruments exists and indicates their key role in the management process.

The relationship between the degree of use of a specific management instrument and the management concept in place within an organization cannot be overlooked. J. Teczke believes that the description of the concept of organizational management is possible in functional and structural terms (Teczke, 1996, p. 6). In the first dimension, it is understood as the process of controlling the functions of organizing, implementing and controlling, and depends on the size of the organization and the degree of its development (Teczke, 1996, p. 6). In structural terms, the management concept includes the structure of the organization, the management system with its subsystems of enterprise policy and planning, the administration and information and control subsystem, management methodology, including elements, means and methods of management, the management team with its competences, value system, opportunities for development and behaviour (Teczke, 1996, p. 6). This means that the place of shaping the image in the instrumentation of management in functional and structural terms is dependent on the characteristics of the organization, its specifics, level of development, structure, system and management subsystems, staff and values. In structural terms, it directly depends on the management methodology, including the management instruments used. This is confirmed by K. Dobrzański, who writes that increasing decentralization in organization management favours 
greater flexibility in the implementation of various management instruments, which is associated with the adequacy of their use at various levels of management (1995, p. 36).

W. Kowalczewski and J. Nazarko defined the relationships between the management concept and management instruments slightly differently, and treated the concept as a new idea, project, action plan (2006, p. 16). In their opinion, the implemented management concept becomes a method that over time transforms into a set of techniques of routine activities that are constantly repeated, i.e. functions (Martyniak, 2001, p. 16). A method is a specific way of acting or doing something, consciously implemented in certain cases of a given type. This can be seen in the example of public relations or marketing, which were originally management concepts rather than methods, and are now treated as company functions (Kowalczewski, Nazarko, 2006, p. 15). Techniques that describe specific activities in more detail are an integral part of the methods (Jankowiak, 2008, p. 53); they are a routine set of rules and rules of operation included in programs, algorithms or procedures. Consequently, this management instrument is understood by W. Kowalczewski and J. Nazarko as a broad concept of content, containing concepts, methods and management techniques (2006, p. 18). B. Mikuła, referring to knowledge management, also justifies that the scope of instruments may include organizational systems, tools and methods (2006, p. 122). For this reason, in some publications, the instrument is treated as being all kinds of means to achieve set objectives at various levels of management (Śliwa, 1978, p. 9), and the instrumentarium is as a whole, is the ways and methods through which these goals can be achieved (Kowalczewski, Nazarko, 2006, p. 18). This approach corresponds to the definition of the instrument adopted by J. Marciniak, who assumed that these are the concepts of thinking and behaviour, as well as tools for solving specific theoretical and practical problems (2008, p. 9). This is in line with the opinion of J. Lichtarski, who as one of the precursors of the discussed subject, noted that the instruments constitute a management system in the enterprise that includes a set of related ideas, principles and methods, techniques and tools (Lichtarski, 1999).

Therefore, their classification seems to be a good explanation of the term management instrument. It may, as H. Jagoda and J. Lichtarski want, take a hierarchical form distinguishing three levels:

a) a concept related to philosophy, orientation, general approach,

b) the general method and

c) the detailed method, technique, tools (Jagoda, Lichtarski, 2003, p. 3).

Or referring to the level of detail, be more extensive, indicating that management instruments are:

- principles, i.e. general principles, indicators and management guidelines,

- general methodologies, i.e. management strategies, e.g. specifying the stages of the procedure, selection of methods and techniques, 
- general methods that guide actions at individual stages of the management process,

- groups of detailed methods, understood as a set of methods with similar functionality, serving similar purposes: e.g. value analysis,

- detailed methodologies indicating the use of detailed methods and techniques in individual phases and stages of operation,

- groups of techniques,

- individual techniques (Kowalczewski, Nazarko, 2006, p. 19).

In the literature on the subject there is also a division of management instruments consistent with the areas of management, in which there are strategic management instruments, marketing instruments, knowledge management instruments, information and logistics technology management instruments, human resource management instruments and quality management instruments (Kowalczewski, Nazarko, 2006, p. 20).

In the light of the above classifications and references to the perception of the management instrument by various authors, including: H. Jagoda and J. Lichtarski, S. Marciniak, W. Kowalczewski, J. Nazarko and B. Mikuła, they are assumed to be various types of measures to achieve the goals of the organization or solve specific theoretical and practical problems; in the organization they form a management system, including organizational systems, thinking and behaviour concepts, methods, processes, tools and techniques enabling the implementation of the management function.

\section{Shaping the image of the organization as a management instrument}

It seems logical that since image formation is an important dimension of the activities and endeavours of a modern organization, it should be assumed that there are management instruments adequate to this activity. Currently, in theory and practice, it is observable to expand the scope of management instruments, which is associated with the development of existing and the emergence of new management instruments, for example, related to information and information technologies (Wąchol, 2010, p. 155). It also has to do with the creation of new ideas and paradigms that affect concepts, methods and techniques that give the management system an original shape (see also: A. Siemionek, M. Siemionek-Ruskań, pp. 98-99). As noted by S. Marciniak, the main premise is the demand arising from business practice and the need for organizational flexible response to the changing conditions of their functioning (2008, p. 9). 
Considering the place of shaping the image of an organization in management instruments, it is worth emphasizing that management itself is a process shaping the image of the organization (Zacłona, 2011, p. 154). Image is a derivative of management because it is also a dimension of the organization's assessment and perception (LeBlanc, Nguyen, 1996, p. 48). The management paradigm functioning in the organization translates into its perception, especially in the internal environment, but also directly and indirectly affects the external environment. The implemented management concept also has an impact on employee behaviour, and, through their interactions with stakeholders, affects the emerging image of the organization. The place of shaping the image in the management instruments is also interdependent with the goals of the organization that underlie its functioning (Kraley, 2011, p. 83). If the goal of the organization is to build a positive image, it even more affects the management processes that must be properly shaped. This is essentially reflected in the method of management by objectives (Management by Objectives, MBO and Teczke, 1996, p. 18). It assumes orientation towards the result of the activity by aligning the goals of individual members of the organization, individual departments and other units with the goals of the organization (Teczke, 1996, p. 18). This method consists in setting a specific goal and obtaining the desired result, however, leaving some freedom as to how to achieve it. Although MBO raises some doubts (Wilk, 2010, p. 16), it can be assumed that managing the image shaping process is one of the highest levels of organization control and as such should be integrated with its development at all levels. This is due to the self-definition mechanism by consciously creating the image of the organization, which, in consequence, leads to its differentiation from other entities and creates its added value (Howard, 2012, p. 1).

W. Budzyński noted that many management theories and concepts ignore the issue of image, underestimating its key role in company management (2008, p. 41). He also noticed that image and its shaping are undeniably related to organization management, therefore, he underlined the relationship between image shaping and overall organization management. In the developed model, he assumed that in the field of organization management, one can distinguish operation management and organization image management, and the high degree of coupling between them. As part of operations management, he included management of work resources, marketing, information, projects, logistics, quality and finances (fig. 1) (Budzyński, 2002, p. 67). In the area of image management of the organization, however, he wrote that it included internal communication, reputation, crisis and lobbying management. 


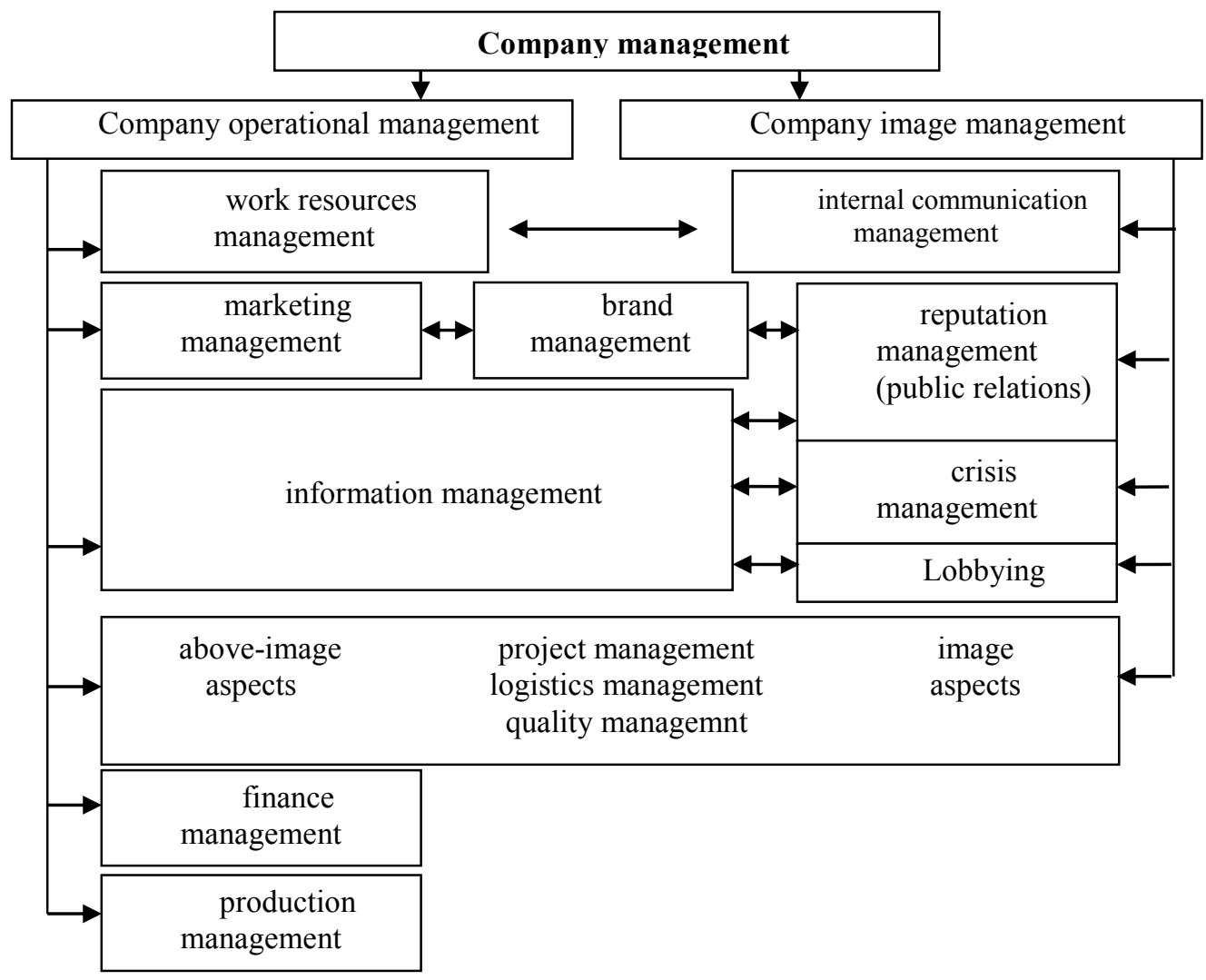

Figure. 1. Place of image management in the concept of organization management. Adapted from: "Wizerunek firmy: kreowanie, zarządzanie, efekty" by Budzyński. Copyright 2002 by Poltext Warsaw.

Indications for the place and importance of shaping the image in the instruments can be found in the concept of strategic management. It can be assumed that the basis of strategic management is the strategy of action that allows achieving the long-term goals of the organization (Wójcik-Augustyniak, 2008, p. 133-134). For a strategy to be comprehensive, it must take into account the expectations of stakeholders and include a long-term policy of communicating the organization with the environment, including image creation (Budzyński, 2002, p. 92). This need results from the basic planes of activities in the area of strategic management, focused (among others) on creating proper relations of the organization with the environment, introducing intra-organizational changes in order to respond to the changing requirements of the environment (Banaszek, 1997, p. 43), and adapting the resources and intentions of each level of management to the overall vision of the organization (Czekaj, 2007, p. 168). This requires a close link between the overall strategy of the organization and the socalled functional strategies focused on important areas of the organization's activities (Glińska, 2008, p. 71). These strategies are to implement the company's goals within its basic functions (Urbanowska-Sojkin, 1998, p. 149). J. Penc pointed out that integrated management should take into account the links between the basic functions of the organization and its individual strategies, because such management must combine various approaches and knowledge, showing comprehensiveness and taking into account phenomena and processes occurring inside and outside the organization (Penc, 2006, p. 71). Therefore, in addition to the overall development strategy, the organization should also have an image shaping strategy, which in 
the literature on the subject is often called the identity strategy; it is a planned set of instruments shaping identity and image, resulting from the adopted mission (Stanowicka-Traczyk, 2008, p. 26), which in itself is the element that distinguishes the organization (Maliszewski, 2008, p. 125). This was stressed by T. Żyminkowski, who emphasized that the adopted mission expresses the basic features of the image desired by the organization (Żyminkowski, 2003, p. 44). Thus, the mission of the organization should define its role towards the environment (Białecki, 2001, p. 84), in other words, how it should be perceived by the environment.

Due to the fact that image creation is equally often classified as an instrument building strategic competitive advantage and as an important element of the overall development strategy (Olszewska, 2000, p. 12), activities in its area should not be narrowed down only to functional strategy, as the designed and created image should permeate all levels of strategic planning. For this reason, elements related to shaping the image should also be reflected in the overall strategy and in all functional strategies of the organization.

The theoretical achievements and practical achievements of public relations (PR), the strategic role of which in managing the organization seems to be undeniable, also provide information about significant relationships between the image and organization management (Zacłona, 2011, p. 154). Although the image of the organization is ignored in many theoretical management models, the above arguments - presented on the basis of literature analysis - argue that treatment of image shaping as a management instrument is right, while pointing to its significant importance in management instruments. Building the right image, being an important goal of the organization, is coupled with the management process, because management is directly and indirectly affecting the emerging image of the organization. Moreover, such a goal requires in the area of image shaping the implementation of management instruments that must be associated with the overall management of the organization. Among other issues, for this reason, the current image can also be treated as an intangible measure and result of management efficiency. The growing importance of image as a management instrument is also evidenced by modern business practice, in which, in addition to shaping the image, organizations increasingly create the image of a product or service that is "closer to the consumer" through the purchasing process. Creating a positive image of a brand or product in the eyes of the customer has a very large impact on his/her purchasing perception in the next contact with the product or service, because the buyer recognizes the product, has smaller shopping doubts and bears less consumer risk. The literature presents numerous definitions of the image of a brand or product, which is often referred to as a dynamic set of comments, impressions, thoughts, feelings shared by an individual or group with respect to a selected fragment of reality. Regarding the brand or product image, different areas can be specified that can be defined as follows: image of the purchase situation; image of a typical brand or product user; image of product functions, parts and features; image of functional benefits; image of specific customer experiences using the product; image of symbolic benefits, including the 
prestige and market acceptance enjoyed by brands or products, and the perception of the personality of a company brand (Wereda, Zacłona, 2011, pp. 268-269).

\section{Method and characteristics of the study}

To achieve the goal adopted in the article, a survey was conducted aimed at managers of selected tourist accommodation establishments - hotels, motels and boarding houses. The research covered three regions: southern, eastern, southwest. This choice was due to the personal availability of tourist managers of accommodation facilities located in these parts of Poland. The research was carried out in the period February-May 2018. To determine the place and importance of image formation in the management structure of the analyzed tourist accommodation establishments, the study diagnosed:

- whether they carry out conscious activities aimed at creating their image,

- whether and for what period they plan activities to shape their image,

- do they examine their image,

- whether in the overall development losses of these entities, there are references to shaping their image,

- whether there is a strategy for shaping image or identity in their management structure,

- do these entities have image creation procedures,

- whether they have organizational units or persons responsible for shaping the image,

- what is the responsibility of top management for shaping their image.

As a result of the research, 112 correctly completed questionnaires were collected, which were used for analysis and inference. The research used the social survey method, and Table 1 contains a detailed description of the research.

Table 1.

Detailed description of the research

\begin{tabular}{|c|l|}
\hline $\begin{array}{c}\text { Area } \\
\text { presented research } \\
\text { section }\end{array}$ & The practice of shaping the image by collective accommodation facilities. \\
\hline Research tool & Survey form completed directly and electronically \\
\hline Research period & 4 months (from 01/02/2018 to 31/05/2018) \\
\hline Study population & $\begin{array}{l}\text { Managers from Polish tourist accommodation establishments, from the highest and } \\
\text { middle management level, making decisions in the field of marketing activities, } \\
\text { external communication and shaping the image. }\end{array}$ \\
\hline $\begin{array}{c}\text { Selection criterion for } \\
\text { the research sample }\end{array}$ & Availability of respondents from all over Poland. \\
\hline
\end{tabular}


Cont. table 1.

\begin{tabular}{|c|l|}
\hline $\begin{array}{c}\text { The size of the } \\
\text { research sample } \\
\text { finally accepted for } \\
\text { analysis }\end{array}$ & 112 managers. \\
\hline $\begin{array}{c}\text { Types of } \\
\text { enterprises } \\
\text { managed by the } \\
\text { surveyed managers }\end{array}$ & $\begin{array}{l}\text { According to criteria such as: type of collective accommodation facility (87 - hotels, } \\
6-\text { motels, 19- guesthouses). All surveyed enterprises were all-year tourist } \\
\text { accommodation establishments. }\end{array}$ \\
\hline $\begin{array}{c}\text { Ways to conduct } \\
\text { research }\end{array}$ & $\begin{array}{l}600 \text { forms were printed out, which were distributed to managers of collective } \\
\text { accommodation facilities during fairs, scientific conferences and directly at the entities } \\
\text { in which they worked. The questionnaire was also available in an electronic version and } \\
\text { sent to people on the contact details database conducting the research. The respondents } \\
\text { gave in person or sent completed research tools to the correspondence address provided } \\
\text { in the form or sent it to the e-mail address provided. The survey was anonymous. }\end{array}$ \\
\hline Return of surveys & $\begin{array}{l}\text { Managers submitted 126 completed questionnaires, of which 112 were correctly and } \\
\text { completely completed for further applications. }\end{array}$ \\
\hline
\end{tabular}

\section{Research results and conclusions for the practice}

In the surveyed population, the vast majority of entities (86) carried out conscious actions aimed at creating their image, of which 85 planned these actions in advance. The collected empirical material showed that the most numerous group of surveyed entities planned image and creative activities in a perspective of one to three years, while the second most popular strategy in the examined group was planning these activities for a period shorter than one year. The aforementioned is illustrated in Figure 2.

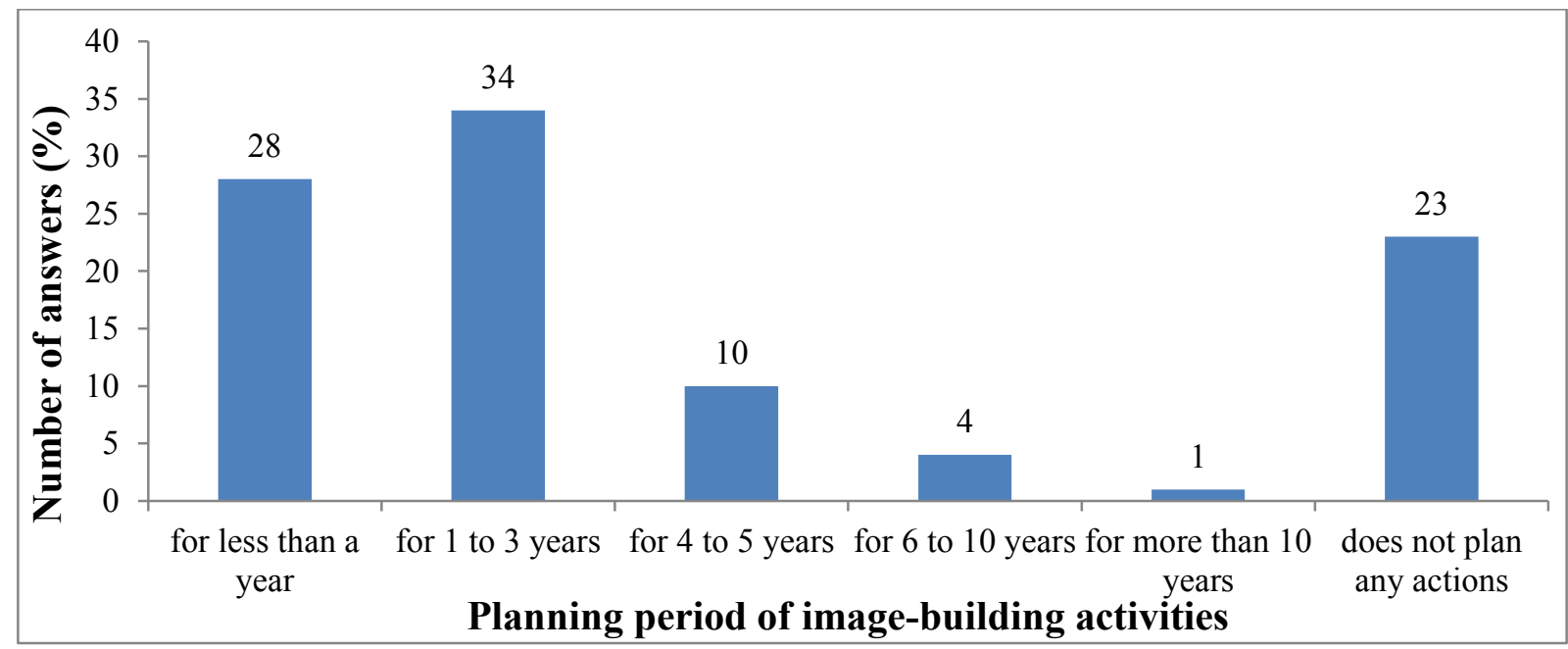

Figure 2. The period of planning image-creative activities by the tourist accommodation facilities studied $(\mathrm{N}=112)$

The planning process forces image research in the broad environment of the organization. Lack of awareness of one's own image and how a given entity is perceived would categorize activities in the area of its shaping as intuitive and unprofessional. Due to the deferred 
perspective of achieving the effects of image-creative activities, it is necessary for an entity to regularly research own image to determine how it evolves. The collected empirical material shows that in the group of respondents, $63 \%$ conducted research on their own image, which is presented in Table 2.

Table 2.

Conducting research on one's own image in a group of analyzed tourist accommodation establishments

\begin{tabular}{|c|l|c|}
\hline No. & \multicolumn{1}{|c|}{ Variants of answers to the question } & Number of answers \\
\hline 1. & Tourist accommodation establishments conducting image research & $\mathbf{6 3 \%}(\mathbf{7 1 )}$ \\
\hline $\mathbf{2}$. & Tourist accommodation establishments not conducting image research & $\mathbf{2 7 \%}(\mathbf{4 1})$ \\
\hline$\sum$ & $\mathbf{1 0 0 \%}(\mathbf{1 1 2})$ \\
\hline
\end{tabular}

The importance of shaping the image as a management instrument can also be confirmed by references to it in the general development strategies of the examined objects and the existence of separate strategies for shaping the image or identity, as well as the existence of procedures for shaping the image. In the surveyed population, 89 entities had a general development strategy, of which 63 objects contained references to shaping the image. Much less, because only 31 collective accommodation facilities had a functional strategy in shaping the image or identity, the same entities also had formulated image-shaping procedures. It also turned out that 67 of the surveyed entities had organizational units responsible for shaping the image. Moreover, managers participating in the survey determined on the scale of aggregated assessments, the percentage responsibility of top management, middle management, operational management level and specialists and regular employees for shaping their image. Empirical material shows that respondents assigned the highest responsibility for shaping the image to top-level managers, a summary of the results obtained is presented in Figure 3.

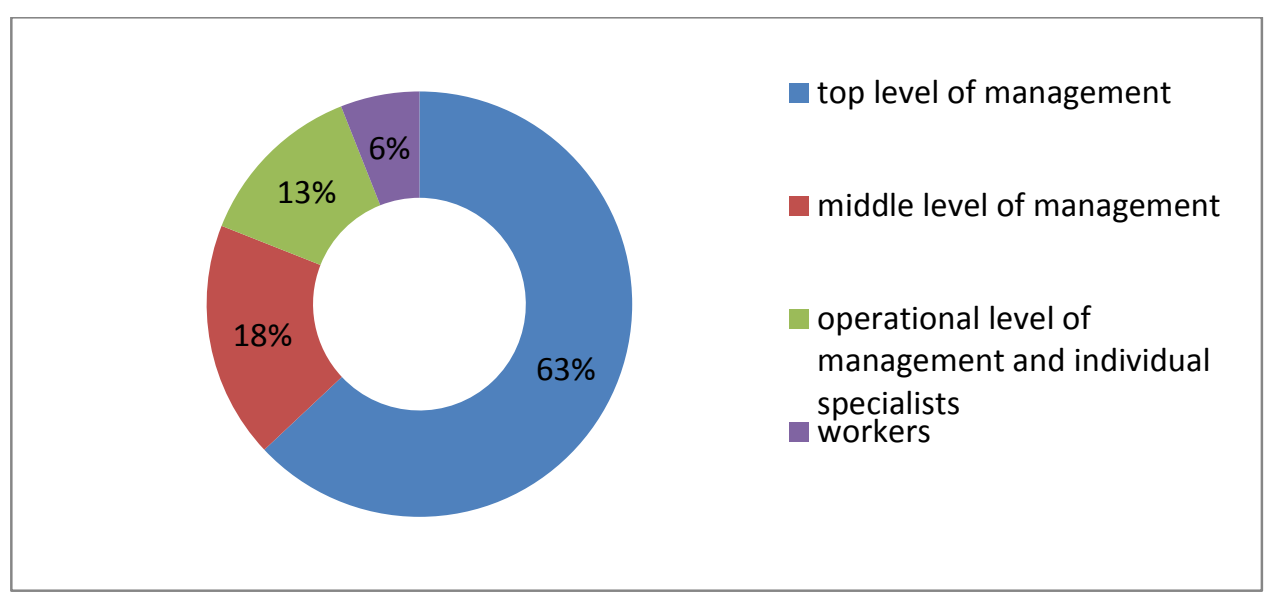

Figure 3. Responsibility for shaping the image of people working at various levels of the organizational structure in the entities surveyed $(\mathrm{N}=112)$. 
In the study, the respondents' attitudes towards the following statements was also diagnosed:

- image formation is an organization management tool,

- the strategic goal of managing an organization should be to build its positive image in the eyes of its stakeholders, both external and internal,

- the image of the organization is its strategic resource and a factor of its competitive advantage on the market,

- financing of activities shaping the image is, according to the respondents, a waste of money.

The collected empirical material indicates that the surveyed managers believed that image formation is a management tool, as many as $92 \%$ of respondents strongly agreed with this statement (the list of answers is presented in Table 3 ).

Table 3.

Attitudes of respondents towards image creation

\begin{tabular}{|l|c|c|c|c|c|}
\hline & $\begin{array}{c}\text { I definitely } \\
\text { agree }\end{array}$ & $\begin{array}{c}\text { I rather } \\
\text { agree }\end{array}$ & $\begin{array}{c}\text { I neither agree } \\
\text { nor disagree }\end{array}$ & $\begin{array}{c}\text { I rather } \\
\text { disagree }\end{array}$ & $\begin{array}{c}\text { I strongly } \\
\text { disagree }\end{array}$ \\
\hline $\begin{array}{l}\text { Shaping the image is a management } \\
\text { tool }\end{array}$ & $92,0 \%$ & $8,0 \%$ & $0,0 \%$ & $0,0 \%$ & $0,0 \%$ \\
\hline $\begin{array}{l}\text { The strategic goal of managing an } \\
\text { organization should be to build its } \\
\text { positive image }\end{array}$ & $83,9 \%$ & $9,8 \%$ & $6,3 \%$ & $0,0 \%$ & $0,0 \%$ \\
\hline $\begin{array}{l}\text { The image of the organization is its } \\
\text { strategic resource and a factor of its } \\
\text { competitive advantage }\end{array}$ & $84,8 \%$ & $12,5 \%$ & $2,7 \%$ & $0,0 \%$ & $0,0 \%$ \\
\hline $\begin{array}{l}\text { Financing image-shaping activities } \\
\text { is a waste of money }\end{array}$ & $0,0 \%$ & $1,8 \%$ & $20,5 \%$ & $12,5 \%$ & $65,2 \%$ \\
\hline
\end{tabular}

Most respondents (105) also agreed with the statement that the strategic goal of managing an organization should be to build its positive image. The respondents (109 people) were also convinced that the image of the organization is its strategic resource and a factor of its competitive advantage. The vast majority of managers (87) covered by the survey disagreed with the statement that financing image-shaping activities is a waste of money.

\section{Conclusions}

The performed studies, due to their limited scope, cannot be used for generalizations and are treated by the authors themselves as pilot studies. However, in their opinion, they provide testimony that image formation is a management instrument implemented in tourist accommodation establishments. The research also confirmed the awareness of the managers in the survey regarding the treatment of image shaping as a management instrument. In addition, most managers emphasize that the strategic goal of managing an organization should be to build 
its positive image in the eyes of its stakeholders, both external and internal, which translates into competitiveness, recognition on the market, and ultimately on the company's financial results. Based on the conducted literature analysis and completed research, the following recommendations can be formulated for managers of tourist accommodation establishments:

- image formation should be linked to the management of the whole enterprise,

- the strategic goal of management should be to build its positive image,

- managers should plan image and creative activities in the long and short term,

- to make adequate decisions, cyclical research on the image of a given accommodation facility should be conducted,

- there should be a strategic document in the enterprise regarding image development, e.g. image development strategy,

- image building instruments should be defined in the building,

- tasks and responsibilities of individual persons and organizational units should be clearly defined with regard to shaping the image of the enterprise,

- in shaping the image, care should be taken to ensure effective internal and external communication,

- it is advisable to develop a crisis strategy.

\section{References}

1. Banaszek, P. (1997). Zarządzanie strategiczne. In: R. Banaszek, and R. Fimińska-Banaszek, and A. Stańda, (Ed.), Zasady zarzadzania w przedsiębiorstwie [Principles of management in an enterprise], Poznan: Wydawnictwo Wyższej Szkoły Bankowej.

2. Białecki, I. (2001). Misja. In: M. Wójcicka. (Ed.) Jakość ksztatcenia w szkolnictwie wyższym. Słownik tematyczny, Warsaw: Centrum Badań Polityki Naukowej i Szkolnictwa Wyższego Uniwersytet Warszawski.

3. Biedermann, M. and Urbaniak, M. (1998). Image - czynnikiem sukcesu firmy. Marketing i Rynek, 11 .

4. Budzyński, W. (2002). Wizerunek firmy: kreowanie, zarzadzanie, efekty [Firm`s image: creation, management, effects]. Warsaw: Poltext.

5. Budzyński, W. (2008). Wizerunek równoległy. Nowa szansa promocji firmy $i$ marki [Parallel image. A new opportunity to promote your firm and brand]. Warsaw: Poltext.

6. Czekaj, J. (2007). Metody organizacji $i$ zarzadzania [Organization and management methods]. Krakow: Wydawnictwo Akademii Ekonomicznej. 
7. Dobrzański, K. (1995). Diagnoza instrumentów zarządzania w organizacjach usług społecznych. Instrumenty zarządzania współczesnym przedsiębiorstwem. Zeszyty Naukowe AE Poznań - Seria I, 236, 23-36.

8. Glińska, E. (2008). Zarządzanie procesem kształtowania wizerunku miasta wśród jego mieszkańców na przykładzie Zambrowa [Process management of shaping the city`s image among its inhabitants on the example of Zambrów]. Torun: Wydawnictwo Adam Marszałek.

9. Howard, S. (2004). Corporate Image Management: A Marketing Discipline for the 21st Century, Retrieved from http://www.howard-marketing.com/images/File/resource pdf/cim-1.pdf, 21.11.2014.

10. Jagoda, H., and Lichtarski J. (2003). O istocie i ewolucji współczesnych koncepcji i metod zarządzania przedsiębiorstwem. Przegląd Organizacji, 1, 3-6.

11. Jankowiak, R. (2008). Instrumenty zarządzania jakością. Zeszyty Naukowe Instytutu Ekonomii i Zarzadzania Politechniki Koszalińskiej, 12, 51-64.

12. Kowalczewski, W., Nazarko, J. (2006). Przegląd stosowanych instrumentów zarządzania In: W. Kowalczewski, J. Nazarko (Eds.), Instrumenty zarządzania współczesnym przedsiębiorstwem (pp. 15-39). Warsaw: Difin.

13. Kralev, T. (2011). Management by objectives: management philosophy for prosperous tourism organizations. UTMS Journal of Economics, 2, 1. Skopje: University of Tourism and Management, 83-87.

14. LeBlanc, G., Nguyen, N., (1996). Cues used by customers evaluating corporate image in servicefirms. International Journal of Service Industry Management, 7, 2, 44-56.

15. Lichtarski, J. (1999). Współczesne koncepcje zarządzania przedsiębiorstwem - istota, relacje, problemy stosowania. Przegląd Organizacji, 1, 13-18.

16. Maliszewski, T. (2008). Problemy (nie)etyczne a budowanie przewagi konkurencyjnej wyższej szkół niepublicznych. Nauka i Szkolnictwo Wyższe, 1/31, 117-133.

17. Marciniak, S., Ostaszewski, J. (Eds.) (2008). Nowoczesne instrumenty zarzadzania [Modern management instruments]. Warsaw: Wydawnictwo SGH.

18. Martyniak, Z. (2001). O koncepcjach zarządzania raz jeszcze. Ekonomia i Organizacja Przedsiębiorstwa, 4, 81-83.

19. Mikuła, B. (2006). Organizacje oparte na wiedzy [Knowledge-based organizations]. Kraków: Wydawnictwo Akademii Ekonomicznej.

20. Olszewska, J. (2000). Wizerunek jako narzędzie tworzenia przewagi strategicznej gminy. Marketing i Rynek, 11, 14-15.

21. Penc, J. (2006). Sztuka skutecznego zarzadzania [The art of effective management]. Kraków: Oficyna Ekonomiczna.

22. Siemionek, A., Siemionek-Ruskań, M. (2015). Instrumenty zarządzania współczesnym przedsiębiorstwem. Kwartalnik Kolegium Ekonomiczno-Społecznego Studia i Prace, Szkoła Główna Handlowa, 3, 5, Finanse przedsiębiorstw, 97-107. 
23. Stabryła, A. (1997). Podstawy zarzadzania firma - modele, metody, praktyka [Basics of company management - models, methods, practice]. Kraków-Kluczbork: Drukarnia ANTYKWA.

24. Stanowicka-Traczyk, A. (2008). Kształtowanie wizerunku miasta na przykładzie miast polskich [Shaping the image of the city on the example of Polish cities]. BydgoszczOlsztyn: Oficyna Wydawnicza Branta.

25. Sułkowski, Ł. (2005). Epistemolgia $w$ naukach o zarzadzaniu [Epistemology in management sciences]. Warsaw: PWE.

26. Śliwa, J. (1978). Ekonomiczne instrumenty zarządzania [Economic management instruments], Warsaw: PWN.

27. Tarczydło, B. (2013). Metodyka kształtowania wizerunku marki. Rozprawy monograficzne, 298. Kraków: Wydawnictwo AGH.

28. Teczke, J. (1996). Metody i techniki zarzadzania [Management methods and techniques]. Kraków: Akademia Ekonomiczna.

29. Urbanowska-Sojkin, E. (1998). Zarządzanie przedsiębiorstwem, od kryzysu do sukcesu [Business management, from crisis to success]. Poznań: Wydawnictwo Akademii Ekonomicznej.

30. Wąchol, J. (2010). Nowoczesne instrumenty zarządzania a nadzór korporacyjny. Zeszyty Naukowe Uniwersytetu Szczecińskiego, 611, 155-165.

31. Wereda, W., Zacłona, T. (2011). Creation of trade brand images in a turbulent business environment based on the example of social portals In: E. Skrzypek (Ed.) Improving organizations in knowledge society. Lublin: Wydawnictwo UMCS.

32. Wilk, A. (2010). Ewolucja poglądów i koncepcji Petera Druckera. Przedsiębiorstwo przyszłości. Kwartalnik Wyższej Szkoły Zarządzania i Prawa im. Heleny Chodkowskiej, 3, 9-21. Retrieved from http://www.chodkowska.edu.pl/app_cm3/files/74609.pdf, 10.01.2013.

33. Wojcik, K. (2005) Public relations. Wiarygodny dialog z otoczeniem - podręcznik dla teoretyków, poradnik dla praktyków [Public relations. Reliable dialogue with the environment - a handbook for theoreticians, a guide for practitioners]. Warsaw: Placent.

34. Wójcik-Augustyniak, M. (2017). Proces zarządzania strategicznego. In: S. Kardas (Eds.), Zarządzanie w przedsiębiorstwie. Środowisko, procesy, systemy, zasoby, 147-175. Warsaw: Difin.

35. Zacłona, T. (2010). Zarządzanie wizerunkiem uczelni niepublicznych. In: T. Wawak (Eds.), Komunikacja i jakość w zarządzaniu, 259-269. Kraków: Wydawnictwo Uniwersytetu Jagiellońskiego.

36. Żyminkowski, T. (2003). Ksztattowanie wizerunku banku [Shaping the bank's image]. Poznań: Akademia Ekonomiczna. 